\title{
Spatial variation of volatile organic compounds and carbon monoxide in Blantyre City, Malawi
}

\author{
Mapoma, H. W. T. ${ }^{1 *}$, Zimba J. J. ${ }^{2}$, Utembe W. ${ }^{1}$ and Kosamu I. B. M. ${ }^{1}$ \\ ${ }^{1}$ The Polytechnic, University of Malawi, Private Bag 303, Blantyre 3, Malawi. \\ ${ }^{2}$ Dairibord Malawi Limited, P.O. Box 30647, Chichiri, Blantyre 3, Malawi.
}

Accepted 12 May, 2013

\begin{abstract}
This study assessed variations of ambient volatile organic compounds and carbon monoxide (CO) levels in Blantyre City, Malawi. Volatile organic compounds and carbon monoxide measurement was done using the Multi-Gas Monitor between August and December, 2010. Rapid urbanization and lack of standard enforcement on air pollution as well as lack of data on pollutant levels in the city prompted this study. The study focused on methane volatile organic compounds and non-methane volatile compounds besides carbon monoxide. Results of the analysis showed that non-methane volatile compound levels were highest at public bus terminuses with $12.40 \pm 0.83 \mathrm{ppm}$, and lowest for industrial locations $(2.16 \pm 0.09 \mathrm{ppm})$. However, all points registered zero $(0.00) \mathrm{ppm}$ for methane volatile organic compounds. Similarly, mean levels of carbon monoxide were highest at public bus terminuses with $10.92 \pm 0.74 \mathrm{ppm}$, and lowest for industrial locations $(1.11 \pm 0.13 \mathrm{ppm})$. With the exception of Ginnery Corner, all the sampling points had levels of both parameters within the air quality standards. The study revealed a spatial and diurnal variation of the pollutants in all sampling points. It further revealed that the sources of these pollutants are diverse with vehicular emissions being the main source for Masauko Chipembere highway.
\end{abstract}

Key words: Air pollution, ambient, permissible limit, urban, vehicular emission.

\section{INTRODUCTION}

According to the World Health Organization, about onethird of Africa's disease burden can be attributed to environmental hazards and, among these, air pollution is a significant contributor (Prüss-Üstün and Corvalán, 2006). Rapid urbanization in developing countries has led to increased air pollution due to increased vehicular and industrial emissions (Fenger, 1999; Akimoto, 2003). Examples of atmospheric pollutants include volatile organic compounds (VOCs) and carbon monoxide (CO). The use of fossil fuels (for example, gasoline and coal) is the dominant activity aspect that introduces abundant amounts of VOCs and CO into urban atmospheres (Chow and Chan, 2003; USEPA, 2010; Chen et al., 2011).
Several studies on urban air pollution have been carried out elsewhere (Mendoza et al., 2009; Makra et al., 2010) and impacts of such pollution on human health (Peters et al., 2000; WHO, 2003; Lu et al., 2004) and ecosystem (IPCC, 2007; Fowler et al., 2009) are on record. However, there is no published data on such pollution in Blantyre City and air pollution monitoring is not routinely done.

Although, complete control of air pollution is almost impossible, it is reasonable to expect control of emissions to the lowest possible levels consistent with available technology and within a reasonable cost (Khonje, 2004). Malawi has air quality standards although air quality 


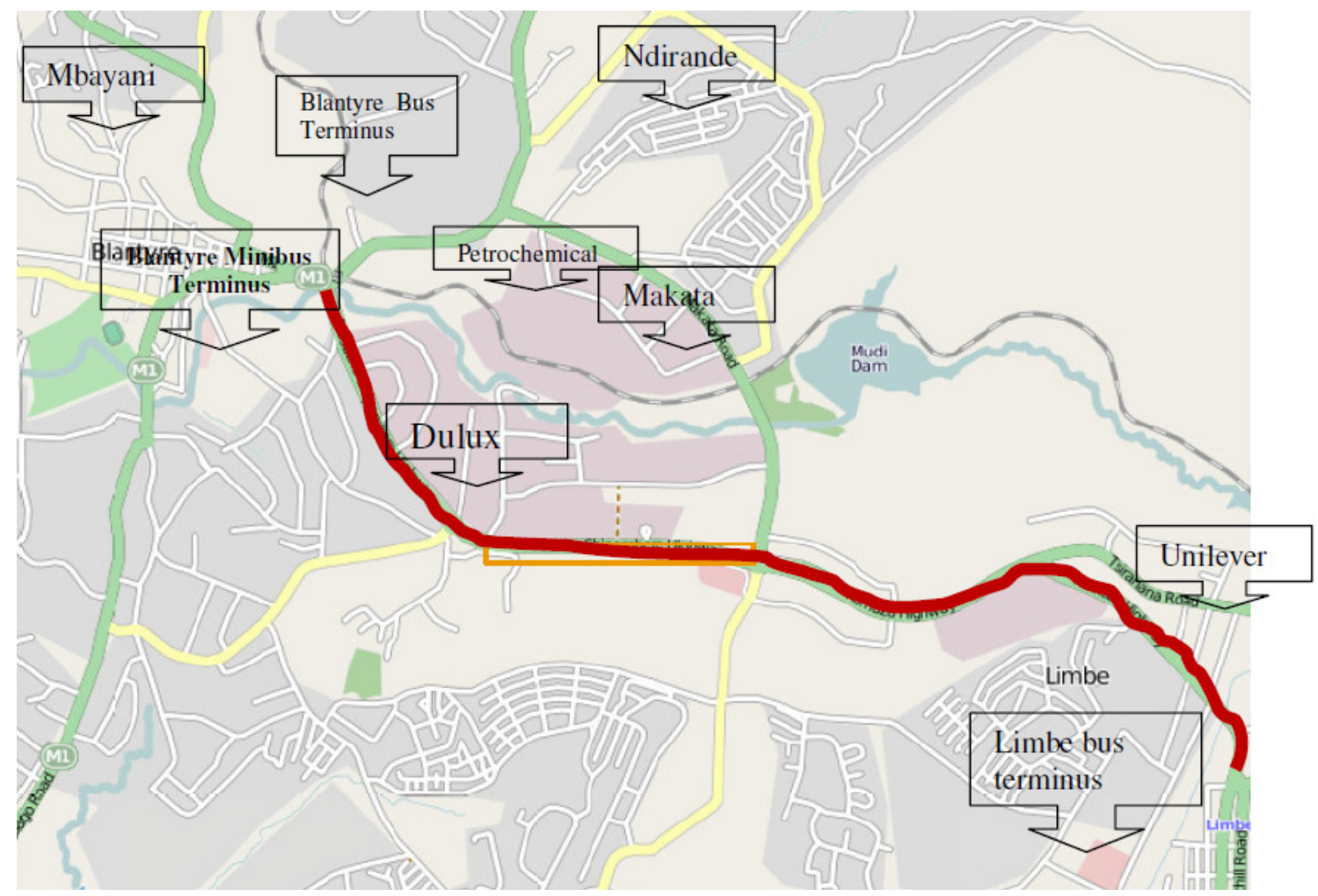

Figure 1. Main sampling points. Red line shows Masauko Chipembere Highway between Blantyre business district and Limbe (adapted and modified from openstreetmap (online)).

Table 1. Summary of meteorological variables obtained from the stationary monitoring system used by the Department of Physics and Biochemical Sciences located along the Masauko Chipembere Highway.

\begin{tabular}{lccccc}
\hline Meteorological variable & Aug & Sep & Oct & Nov & Dec \\
\hline Temperature $\left({ }^{\circ} \mathrm{C}\right)$ & 20 & 23 & 25 & 25 & 24 \\
Precipitation $(\mathrm{mm})$ & & & 21 & 83 & 125 \\
Wind speed $(\mathrm{m} / \mathrm{s})$ & 6.3 & 6.6 & 6.0 & 5.7 & 4.1 \\
Relative humidity $(\%)$ & 56 & 56 & 48 & 59 & 76 \\
\hline
\end{tabular}

monitoring is rarely done. Besides, short-term air quality forecasting, air pollution monitoring and trend-predictions are very crucial because they help in anticipating preventive and evasive action during episodes of elevated air pollution (Makra et al., 2010). Blantyre City is one of such cities where such pollution needs scientific evaluation and monitoring. This study was therefore conducted in order to assess the extent of air pollution in Blantyre City.

\section{MATERIALS AND METHODS}

\section{Study area: Blantyre City}

The assessment study took place in major pollution prone areas within the city, namely: Masauko Chipembere highway, bus/minibus terminus, busiest residential areas and selected industries (Figure
1). The choice of sampling sites was based on anticipated source of emissions (vehicles) and large population. Blantyre City is located in the southern region of Malawi $\left(15^{\circ} 47^{\prime} 10^{\prime \prime S}\right.$ and $\left.35^{\circ} 0^{\prime} 21^{\prime \prime} \mathrm{E}\right)$. Data collection was done between August and December, 2010 (5 months).

During the study period, temperature and wind speed averages were measured by a stationary Air Monitoring System at the polytechnic as indicated in Table 1.

\section{Sampling design and data collection}

Data collection was done using an active mobile multi-gas monitor (Drager X-am 7000 (Online www.draeger.co.uk)) equipped with electrochemical sensors that measured continuous concentrations of VOCs and $\mathrm{CO}$ per $1 \mathrm{~h} 30$ min session during the sampling period. In all the locations, the equipment was placed at $1 \mathrm{~m}$ from the ground to capture maximum emissions from both vehicles and industrial sources. The distance from the anticipated emission source was $1.5 \mathrm{~m}$. Calibration of the instrument was done in fresh air which was free of gases to be measured and suspected to have interfering gases. During data collection, $10 \mathrm{~min}$ consecutive average measurements were recorded during morning (09:00 - 10:30), midday (11:30 - 13:00) and afternoon (15:30 - 17:00), providing 10 sets of values per session per day. This was aimed at ensuring accuracy and reliability of results.

\section{Data analysis and statistical methods}

Results were recorded, processed and analyzed using Microsoft Excel 2007 and SPSS version 16 for windows and results were tabulated. Multiple data collection as well as statistical quality control ensured that data was as accurate as possible. Graphs were 
used to illustrate spatial and diurnal variations as well as regression relationship in VOCs and CO concentrations.

Landau and Everitt (2004) elaborate the statistical procedures employed in this study. To verify whether there were significant spatial and temporal differences in VOCs and CO levels in the study areas, one way ANOVA at 0.05 significance level was used. The independent T-test was used to evaluate differences in levels of NMVOCs and CO between the two residential areas (Ndirande and Mbayani). In a special case, one sample T- test at $95 \%$ confidence level was performed to ascertain whether the 2010 carbon monoxide mean values for Masauko Chipembere highway were higher than those of 2004 (Khonje, 2004) and also whether they were higher than permissible levels.

\section{RESULTS AND DISCUSSION}

\section{Levels of VOCs and CO}

Table 2 presents a summary of NMVOCs and CO concentration levels. The results indicate mean day values split into morning, midday and afternoon. The standard error of mean is included to indicate the reliability of results. However, the summary excludes values of methane simply because all study locations did not register any methane VOCs.

\section{Diurnal and spatial variations in VOCs and CO levels in main locations}

Observations from Table 2 indicate a remarkable variation in diurnal mean values for all sampling locations with a general overview of highest mean values observed for midday period. The outcome of ANOVA analysis indicates a general significant spatial and temporal (diurnal) differences in mean concentrations of NMVOCs and CO in all sampled locations $(p<0.05, F=11.350, F=11.600$, respectively). A least square deviation analysis however showed that there were no significant differen-ces in mean values between morning and afternoon periods of the day in all sampled locations $(p>0.05)$. On the other hand, midday periods for Masauko Chipembere Highway had the highest mean values for both parameters. The phenomenon can be attributed to high traffic intensity that emits large quantities of NMVOCs and CO (Baumbach et al., 1995). Figure 2 presents a picture of the diurnal mean variations in both parameters observed for all sampling locations. Clearly, the midday values are higher than morning and afternoon for bus terminus and Masauko Chipembere Highway.

According to Figure 2, the minibus and bus terminals had the highest concentration of NMVOCs and $\mathrm{CO}$ when compared with the rest of the sites except for midday rush hour due to high intensity of traffic in the main highway. The lowest recorded mean values for both NMVOCs and CO levels were observed for industries along the highway followed by Mbayani area. Diurnal variations are distinctly clear for Bus terminals and highway (Figure 2) unlike the other sites.

In general, for these locations, morning concentrations were lower than midday and afternoon (Figure 2). This exposes the fact that NMVOCs and CO concentrations may be accumulating in the atmosphere, depending on the time of the day. On the other hand, the decrease in concentration in the afternoon as compared to mid-day concentrations is indicative of the atmospheric autoepuration capacity. A special observation is made for the industries along the highway where concentration levels indicate highest mean value in the afternoon period as compared to mid-day and morning session (Table 2 and Figure 2). This is simply due to the operation mode of industries since most of them operate in continuous production mode peaking close to mid-day and resume after lunch.

The independent T-test confirmed that the mean NMVOCs and CO levels for Ndirande and Mbayani residential areas were significantly different $(p<0.05)$. In general, Mbayani residential area had higher morning and afternoon mean NMVOCs record as compared to Ndirande while, the mean $\mathrm{CO}$ values were found to be significantly higher in Ndirande as compared to Mbayani residential area.

\section{Diurnal and spatial variations in VOCs and CO levels in Masauko Chipembere Highway}

Figure 3 is a map of Masauko Chipembere Highway stretching from Limbe to Blantyre business district, while Figure 4 illustrates the diurnal and spatial variations in mean NMVOCs and CO concentrations in the highway.

Sampling point $\mathrm{CH} 4$ (Ginnery Corner) had extreme values according to Figure 4. Ginnery corner is located close to the main referral hospital (Figure 3), a situation that is alarming if these emissions drift and find their way into the wards especially during lunch hour. This may pose a serious health hazard. The highway is the central dual carriage route where most of the vehicles pass through from Limbe to Blantyre and vice versa making it the route with the highest density of traffic passing through during morning, lunch-time and afternoon hours. As such, the areas prone to highest concentration of vehicular emissions are intersections (especially roundabouts) and where small minibuses stop to pick up passengers commuting between Limbe and Blantyre. It is thus reasonable to attribute the concentration of VOCs and $\mathrm{CO}$ to vehicular emissions and that the variations are due to traffic stopping and starting (passenger pickup points) and slowing down into an almost traffic jam at the roundabouts which are not wide enough to provide room for current large volumes of vehicles in the city.

Sampling point $\mathrm{CH} 8$ was observed to have the lowest concentrations of both NMVOCs and CO because the roundabout offers a very wide passage way for vehicles. Vehicles do not normally experience traffic jams at this point, as such, cruising through minimizes the rate of emissions in a given time unlike other sampling points. Between $\mathrm{CH} 1$ and $\mathrm{CH} 3$, both directions experience fast 
Table 2. Summary results of NMVOCs and CO levels in Blantyre City. The results indicate mean levels and their standard error of mean.

\begin{tabular}{|c|c|c|c|c|c|c|}
\hline \multirow{2}{*}{ Sampling point } & \multicolumn{3}{|c|}{ NMVOC (ppm) } & \multicolumn{3}{|c|}{ CO (ppm) } \\
\hline & Morning & Midday & Afternoon & Morning & Midday & Afternoon \\
\hline BT-Limbe (minibuses) & $12.65 \pm 2.02$ & $8.40 \pm 0.81$ & $7.20 \pm 0.81$ & $9.90 \pm 1.22$ & $8.20 \pm 0.84$ & $14.90 \pm 2.37$ \\
\hline BT-Limbe (buses) & $7.00 \pm 1.09$ & $20.30 \pm 4.40$ & $6.30 \pm 0.88$ & $6.30 \pm 0.82$ & $23.10 \pm 4.71$ & $4.30 \pm 0.34$ \\
\hline BT-Mibawa (minibuses) & $6.55 \pm 0.94$ & $10.40 \pm 0.97$ & $7.70 \pm 1.32$ & $6.45 \pm 1.07$ & $3.90 \pm 0.38$ & $10.20 \pm 1.06$ \\
\hline BT-Wenela (buses) & $5.85 \pm 0.84$ & $11.15 \pm 1.14$ & $10.20 \pm 0.89$ & $6.30 \pm 0.73$ & $11.00 \pm 1.21$ & $11.00 \pm 1.21$ \\
\hline IN-Petrochemical & $0.95 \pm 0.12$ & $1.70 \pm 0.32$ & $1.50 \pm 0.28$ & $0.00 \pm 0.00$ & $0.20 \pm 0.20$ & $0.00 \pm 0.00$ \\
\hline IN-Dulux & $2.25 \pm 0.49$ & $1.25 \pm 0.13$ & $1.55 \pm 0.19$ & $0.30 \pm 0.21$ & $0.20 \pm 0.20$ & $1.00 \pm 0.25$ \\
\hline IN-Unilever & $0.95 \pm 0.35$ & $1.15 \pm 0.20$ & $3.50 \pm 0.34$ & $0.70 \pm 0.23$ & $0.20 \pm 0.20$ & $3.35 \pm 0.30$ \\
\hline IN-Makata & $0.95 \pm 0.27$ & $1.15 \pm 0.15$ & $2.15 \pm 0.27$ & $0.40 \pm 0.27$ & $0.20 \pm 0.20$ & $1.80 \pm 0.42$ \\
\hline Mb-Market & $5.40 \pm 0.58$ & $2.90 \pm 0.33$ & $4.45 \pm 0.56$ & $4.90 \pm 0.67$ & $2.05 \pm 0.41$ & $4.20 \pm 0.51$ \\
\hline Mb-Ndalama & $3.55 \pm 0.35$ & $1.75 \pm 0.15$ & $3.65 \pm 0.45$ & $1.80 \pm 0.44$ & $0.65 \pm 0.28$ & $2.40 \pm 0.45$ \\
\hline Mb-Zandeya & $2.10 \pm 0.43$ & $0.90 \pm 0.24$ & $1.85 \pm 0.30$ & $0.45 \pm 0.24$ & $0.35 \pm 0.21$ & $0.70 \pm 0.37$ \\
\hline Mb-Gayisi & $3.40 \pm 0.19$ & $3.75 \pm 0.48$ & $2.95 \pm 0.42$ & $1.30 \pm 0.37$ & $3.20 \pm 0.33$ & $1.30 \pm 0.45$ \\
\hline Mb-Anyamata & $2.40 \pm 0.22$ & $2.55 \pm 0.38$ & $3.75 \pm 0.54$ & $0.30 \pm 0.21$ & $1.85 \pm 0.43$ & $4.20 \pm 0.70$ \\
\hline Nd-Market & $5.40 \pm 0.31$ & $6.10 \pm 0.74$ & $5.35 \pm 0.56$ & $6.70 \pm 0.92$ & $6.70 \pm 0.92$ & $6.30 \pm 0.84$ \\
\hline Nd-Newlines & $4.30 \pm 0.63$ & $0.75 \pm 0.19$ & $2.05 \pm 0.24$ & $0.20 \pm 0.20$ & $0.30 \pm 0.21$ & $2.45 \pm 0.16$ \\
\hline Nd-Chinseu & $1.80 \pm 0.13$ & $5.15 \pm 0.55$ & $4.40 \pm 0.83$ & $4.00 \pm 0.75$ & $4.90 \pm 0.62$ & $5.70 \pm 0.84$ \\
\hline Nd-Zion & $1.10 \pm 0.23$ & $1.20 \pm 0.19$ & $1.60 \pm 0.24$ & $0.30 \pm 0.21$ & $0.20 \pm 0.20$ & $0.00 \pm 0.00$ \\
\hline $\mathrm{CH}-$ Clocktower (CH1) & $4.80 \pm 0.34$ & $15.55 \pm 2.38$ & $6.65 \pm 0.95$ & $4.00 \pm 0.37$ & $13.60 \pm 2.00$ & $3.95 \pm 0.32$ \\
\hline CH-Kristwick (CH2) & $5.95 \pm 0.53$ & $5.45 \pm 0.76$ & $3.65 \pm 0.35$ & $5.70 \pm 0.65$ & $5.20 \pm 0.80$ & $3.30 \pm 0.37$ \\
\hline $\mathrm{CH}-\mathrm{QECH}$ Roundabout (CH3) & $4.75 \pm 0.47$ & $6.00 \pm 0.83$ & $5.60 \pm 0.42$ & $4.50 \pm 0.40$ & $5.80 \pm 0.84$ & $5.85 \pm 0.42$ \\
\hline $\mathrm{CH}$-Ginnery Corner $(\mathrm{CH} 4)$ & $4.20 \pm 0.60$ & $64.20 \pm 12.52$ & $16.65 \pm 5.07$ & $3.90 \pm 0.48$ & $52.40 \pm 12.52$ & $9.10 \pm 2.21$ \\
\hline CH-Polytechnic (CH5) & $7.80 \pm 0.93$ & $10.05 \pm 1.08$ & $5.35 \pm 0.59$ & $7.40 \pm 0.93$ & $10.05 \pm 1.08$ & $5.50 \pm 0.69$ \\
\hline $\mathrm{CH}$-Shoprite bus Stage $\mathrm{CH} 6$ ) & $11.70 \pm 2.34$ & $13.90 \pm 1.11$ & $5.20 \pm 0.52$ & $9.90 \pm 1.88$ & $12.90 \pm 1.35$ & $4.35 \pm 0.51$ \\
\hline $\mathrm{CH}$-Stadium Roundabout (CH7) & $4.85 \pm 0.38$ & $15.35 \pm 3.39$ & $9.05 \pm 1.20$ & $4.30 \pm 0.42$ & $12.80 \pm 2.74$ & $8.30 \pm 1.30$ \\
\hline CH-Maselema Roundabout (CH8) & $4.40 \pm 0.40$ & $4.35 \pm 0.25$ & $5.30 \pm 0.26$ & $4.20 \pm 0.39$ & $4.00 \pm 0.26$ & $5.30 \pm 0.28$ \\
\hline CH-Yiannakis Roundabout (CH9) & $10.15 \pm 1.14$ & $7.00 \pm 0.87$ & $16.50 \pm 1.79$ & $8.70 \pm 0.94$ & $6.75 \pm 0.93$ & $15.60 \pm 1.55$ \\
\hline $\mathrm{CH}-\mathrm{Hardware}$ Stage $(\mathrm{CH} 9)$ & $5.40 \pm 0.60$ & $6.55 \pm 0.69$ & $9.10 \pm 1.43$ & $5.50 \pm 0.62$ & $5.95 \pm 0.80$ & $8.60 \pm 1.54$ \\
\hline
\end{tabular}

Abbreviations preceding the sample site stand for main sampling locations: $\mathrm{BT}=$ Bus Terminus, IN = Industries, Mb = Mbayani residences, $\mathrm{Nd}=$ Ndirande residences and $\mathrm{CH}=$ Masauko Chipembere Highway. Morning = 09:00-10:30, midday $=11: 30-13: 00$ and afternoon $=15: 30-17: 00$.
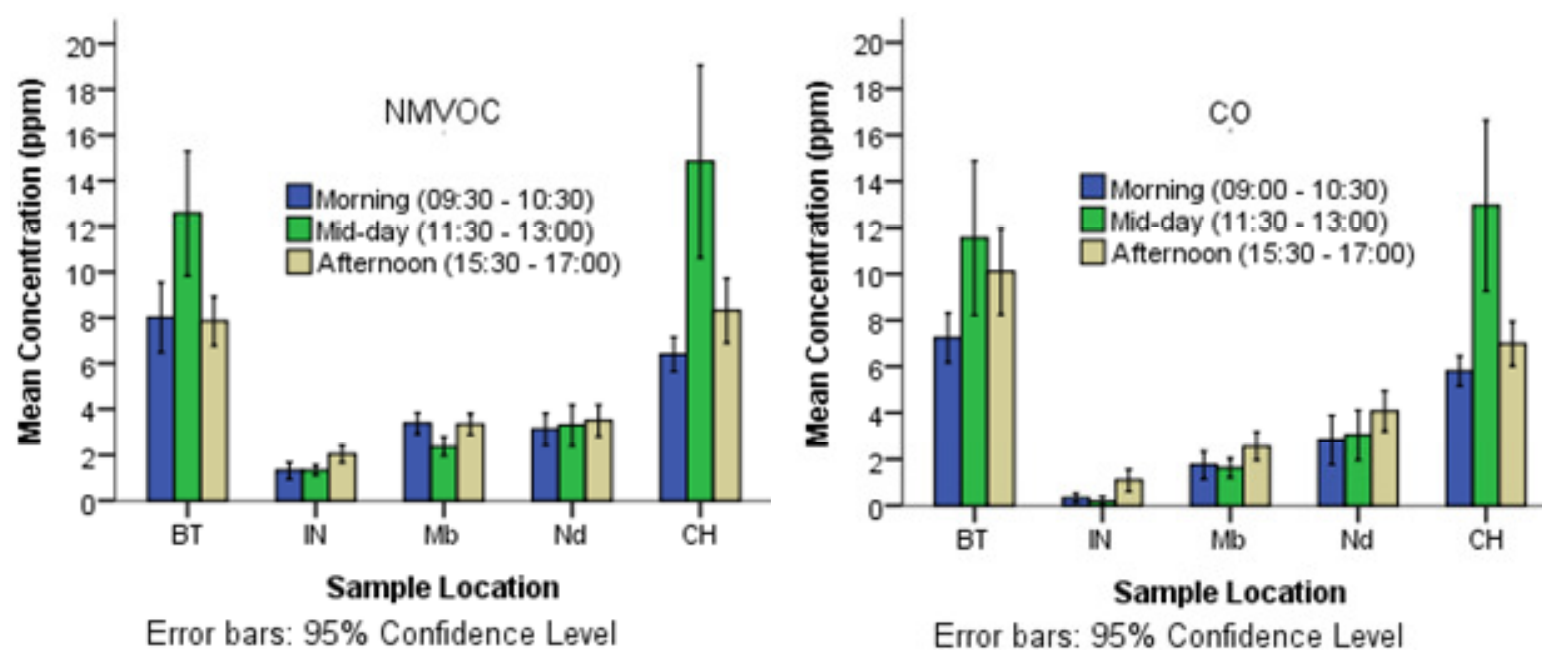

Figure 2. Plot of overall mean values of NMVOCs and CO levels in the main sampling locations. The graphs show diurnal mean variations for each sampling location. BT = Bus terminus, $\mathrm{IN}=$ Industries, $\mathrm{Mb}=$ Mbayani residential areas, $\mathrm{Nd}=$ Ndirande residential area and $\mathrm{CH}=$ Masauko Chipembere Highway. 


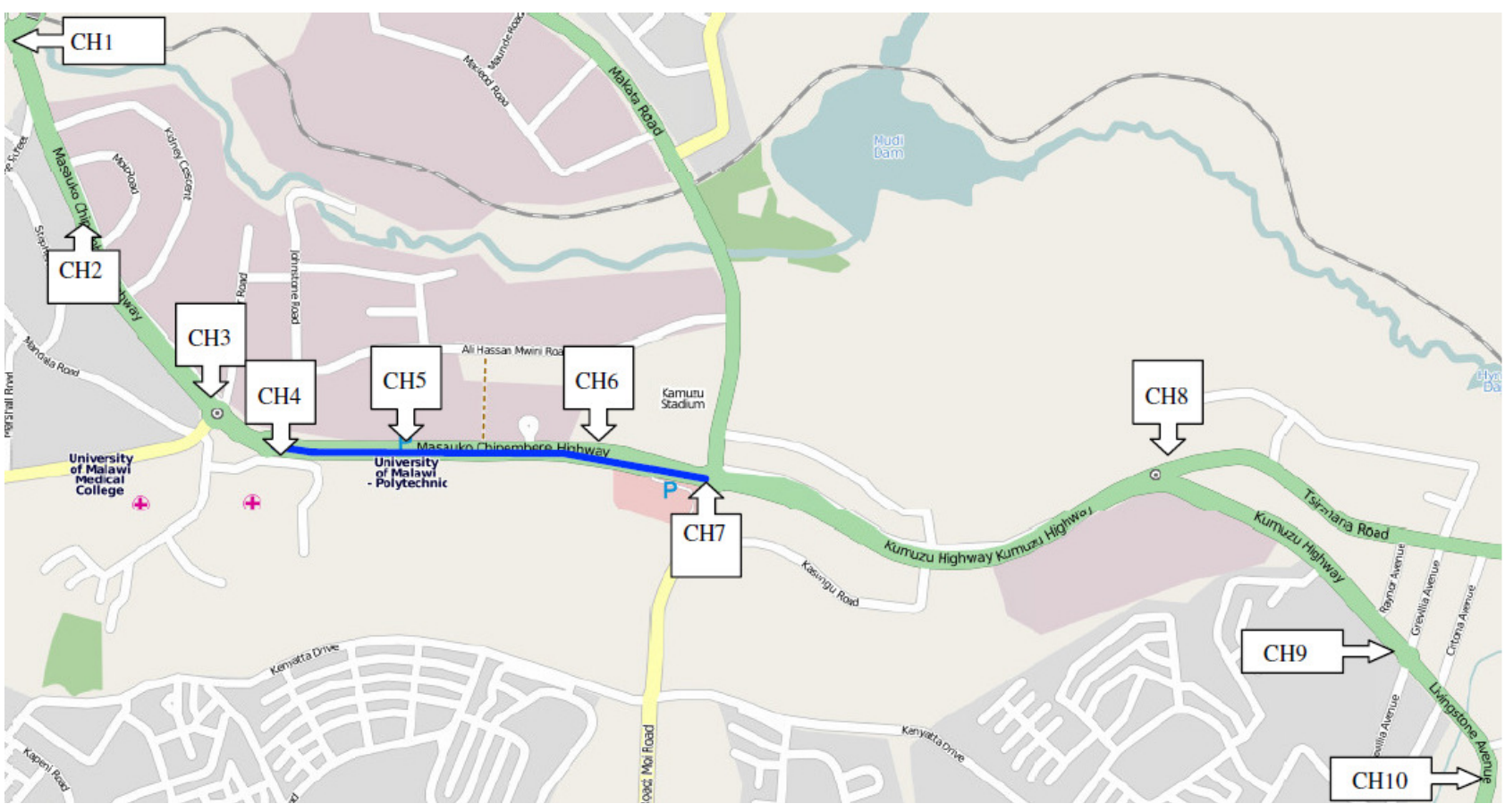

Figure 3. Sampling points along Masauko Chipembere Highway. $\mathrm{CH} 1=\mathrm{Clocktower}$ roundabout, $\mathrm{CH} 2=\mathrm{Kristwick}, \mathrm{CH} 3=\mathrm{Queen}$ Elizabeth Central Hospital Roundabout, $\mathrm{CH} 4=$ Ginnery Corner roundabout, $\mathrm{CH} 5=$ Polytechnic minibus stage, $\mathrm{CH} 6=\mathrm{Shoprite}$ shopping mall stage, $\mathrm{CH} 7$ = Kamuzu Stadium Roundabout, $\mathrm{CH} 8=$ Maselema Roundabout, $\mathrm{CH} 9=$ Yiannakis Roundabout and $\mathrm{CH} 10=$ Hardware minibus stage (adapted and modified from www.openstreetmap.org).
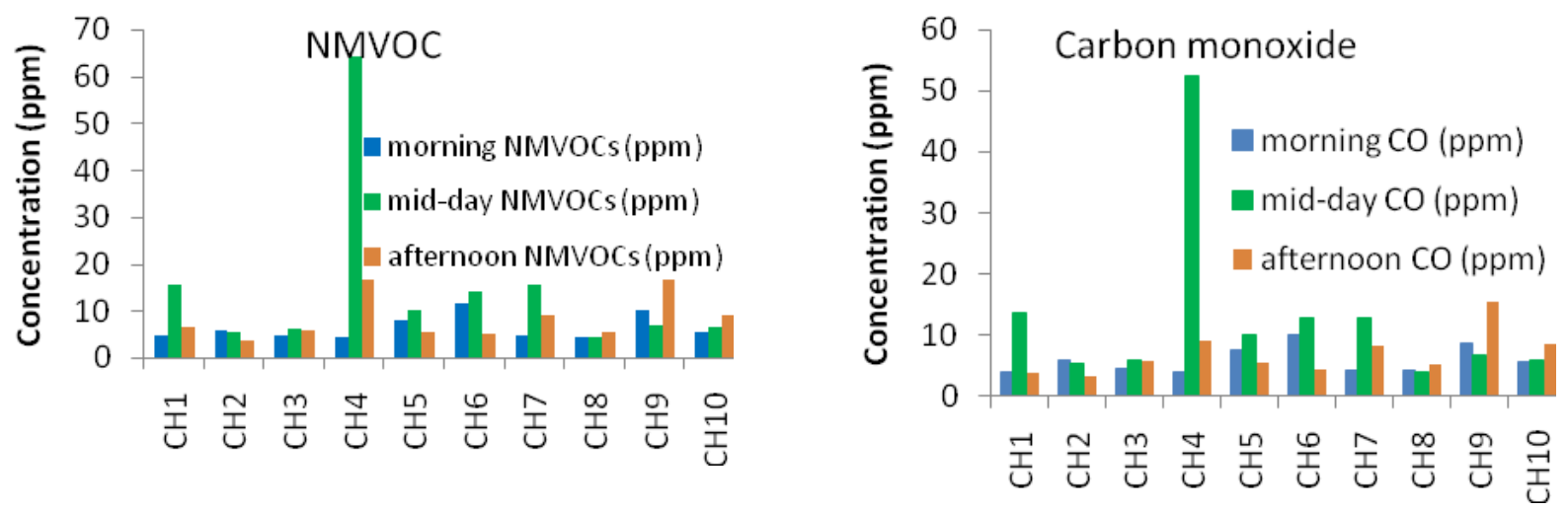

Figure 4. Graphs showing spatial and diurnal variations in NMVOCs and CO levels along the highway from Clock Tower to Hardware Minibus Stage (Limbe). $\mathrm{CH} 1=$ Clocktower roundabout, $\mathrm{CH} 2=$ Kristwick, $\mathrm{CH} 3=$ Queen Elizabeth Central Hospital Roundabout, $\mathrm{CH} 4$ = Ginnery Corner roundabout, $\mathrm{CH} 5$ = Polytechnic minibus stage, $\mathrm{CH} 6=$ Shoprite shopping mall stage, $\mathrm{CH} 7=$ Kamuzu Stadium Roundabout, $\mathrm{CH} 8$ = Maselema Roundabout, $\mathrm{CH} 9=$ Yiannakis Roundabout and $\mathrm{CH} 10=$ Hardware minibus stage.

moving vehicles since the volume of vehicles point to Blantyre or Limbe are reduced in density considering the fact that there are several roads that vehicles can take when moving from Blantyre to Limbe and rejoin the highway at $\mathrm{CH} 3$. On the other hand, between $\mathrm{CH} 4$ and $\mathrm{CH} 8$, the volume of vehicles increases due to joining in of more roadways into the highway at points $\mathrm{CH} 3, \mathrm{CH} 4$ and $\mathrm{CH} 7$. Between $\mathrm{CH} 8$ and $\mathrm{CH} 10$, concentrations are high due to the narrowness of the road since up to date the stretch is not yet developed into a dual carriage way.

\section{Relationship between NMVOCs and CO levels}

Figure 5 shows the relationship between NMVOC and CO concentration levels and elucidate whether the emissions 

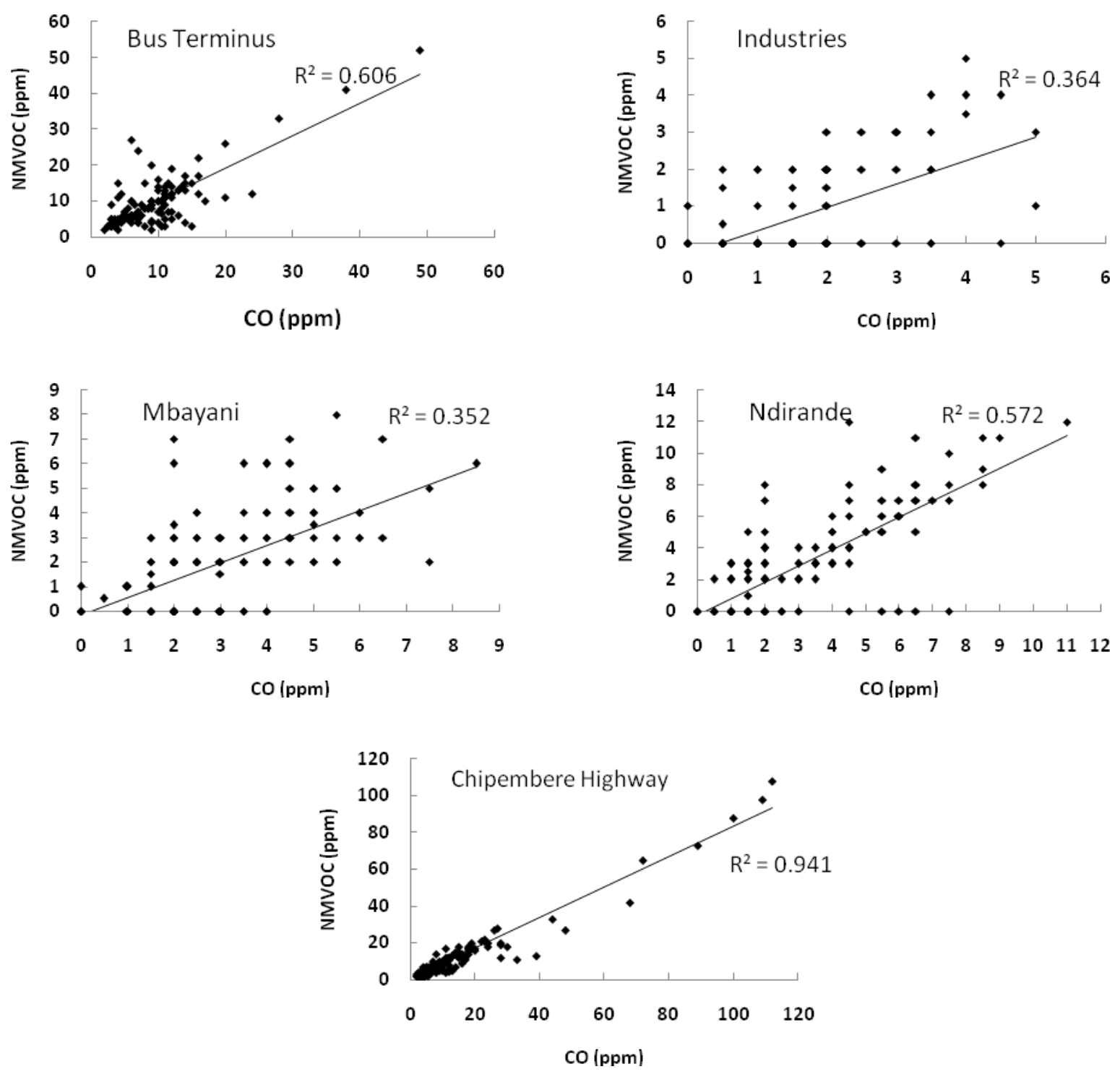

Figure 5. Relationship between VOCs and CO levels in the main sampling locations.

observed are coming from the same sources. In general, the sources, according to the figures, are different. However, for the Bus Terminus and Masauko Chipembere Highway, the cause is vehicular emissions considering the positive relationship exibited by the regressions $\left(R^{2}=\right.$ 0.61 and 0.94 , respectively). This is consistent with the fact that such pollutants are emitted from mobile sources everyday (Lee et al., 2002).

The source of emissions in the industrial area is the manufacturing processes that involve coal burning, solvent utilization and chemical manufacturing. This is why the regression coefficient is low for these sampling points which is a significant contribution to the fact that the sources in these industries depend on the process with coal burning contributing more of the $\mathrm{CO}$ while solvents and petrochemical product lines contributing more of the fugitive VOCs. Despite that, vehicular emis- sions also contribute to the concentration by wind movement since the industries are located in areas where vehicles pass through abait in lower volumes unlike that of the highway. Mbayani residential area has a very low vehicle traffic and is strictly a high density low housing area where you expect very few vehicles to contribute significantly to the emission concentrations. The main source of these emissions are various human activities and small scale business ventures that utilize charcoal and firewood as fuel. On the other hand, Ndirande residential area, despite having low volumes of vehicles, is a thriving business area where various small scale manufacturing, garages and furniture manufacturing is done. Besides, it is the area that has the fuel storage tank for the southern region where most of the incoming fuel (petrol, diessel and parafin) is stocked prior to distribution. As such, these activities together contribute to the 
levels of NMVOCs and CO. Despite a positive relationship, the sources are not necessarily the same in Ndirande.

\section{NMVOC and CO levels compared to Standard Permissible Levels and 2004 Study}

The comparison was made only for $\mathrm{CO}$ due to the fact that, of the two parameters, only the standards for $\mathrm{CO}$ exist in Malawi and also that the previous study concentrated on $\mathrm{CO}$ levels in Masauko Chipembere Highway. It was observed, however, that the mean $\mathrm{CO}$ values for all sites except Ginnery Corner were significantly lower $(p<$ 0.05 ) than the standard $8 \mathrm{~h}$ permissible levels stipulated by Malawi Bureau of Standards (Malawi Bureau of Standards, 2005) and WHO (Colls, 1997).

Morning, mid-day and afternoon carbon monoxide mean levels for Masauko Chipembere Highway (5.81, 12.95 and $6.99 \mathrm{ppm}$, respectively) were then compared with the values $(5.77,5.24$ and $4.95 \mathrm{ppm}$, respectively) obtained for the same study period in 2004 (Khonje, 2004). During the previous study, only $\mathrm{CO}$ levels were recorded and analyzed. The current $\mathrm{CO}$ levels are found to be significantly higher $(p<0.05)$ than those of 2004. Since, according to this study, CO levels in the highway are strongly correlated to NMVOC, same conclusion can be assumed. However, further research is required. This is a serious warning that there is need for consideration of means to reduce emissions in the city as well as safeguard citizens who utilize public transport from the harmful long effects of VOCs and CO. Evidence points to vehicular emissions as that consideration of reducing traffic jams and highways would be a very significant direction in minimizing pollution. Some areas close to hospitals require stringent measures to abate significant emissions.

\section{Conclusion}

This study did not discuss the influence of meteorological variables because at the time of the study, the facility to measure such variables on site where not available. However, it is anticipated that in the ongoing studies, such parameters will be budgeted for and incorporated into the analysis. Despite the fact that the study reveals a spatial and diurnal variation of atmospheric NMVOCs and $\mathrm{CO}$ levels in the busy areas of Blantyre City, vehicular emissions are the main sources of NMVOCs and CO levels in the Masauko Chipembere Highway, while in the rest areas is a combination of activities including vehicles. The study further reveals that vehicular emission of VOCs and $\mathrm{CO}$ in Blantyre City is increasing in the Masauko Chipembere Highway although the levels are still within the Malawi Bureau of Standards and World Health Organization, $8 \mathrm{~h}$ mean permissible limit of 10 $\mathrm{ppm}$. With the current demand for car ownership and lessening usage of public transport in Malawi, it is time to put in place transport policies that will minimize trafficrelated air pollution and safeguard public health.

\section{ACKNOWLEDGEMENTS}

This research was supported by the Department of Physics and Biochemical Sciences at the University of Malawi. The research was made possible with the donation of the multi-gas monitor by Environmental Affairs Department (Malawi). The authors extend their deepest appreciation to Mr. Albert Maliro for the technical support. The anonymous reviewers' input that greatly improved the scientific outlook of this paper is highly appreciated.

\section{REFERENCES}

Akimoto H (2003). Global air quality and pollution. Science 302 (5651): $1716-1719$.

Baumbach G, Vogt U, Hein KRG, Oluwole AF, Ogunsola OJ, Olaniyi HB, Akeredolu FA (1995). Air pollution in a large tropical city with a high traffic density - results of measurements in Lagos, Nigeria. Sci. Total Environ. 169(1-3): $25-31$.

Chen R, Pan G, Zhang Y, Xu Q, Zeng G, Xu X, Chen B, Kan H (2011). Ambient carbon monoxide and daily mortality in three Chinese cities: The China Air Pollution and Health Effects Study (CAPES). Sci. Total Environ. 409(23): 4923-4928.

Chow WK, Chan MY (2003). Field measurement on transient carbon monoxide levels in vehicular tunnels. Build. Environ. 38(2): 227 236.

Colls J (1997). Air Pollution: An Introduction. E \& Fn Spon, London. p. 341.

Fenger J (1999). Urban air quality. Atmos. Environ. 33(29): 4877-4900.

Fowler D, Pilegaard K, Sutton M, Ambus P, Raivonen M, Duyzer J, Simpson D, Fagerli H, Fuzzi S, Schjoerring JK, Granier C, Neftel A, Isaken ISA, Laj P, Maione M, Monks PS, Burkhardt J, Daemmgen U, Neirynck J, Peronne E, Wickink-Kruit R, Butterbach-Bahl K, Flechard C, Tuovinen JP, Coyle M, Gerosa G, Loubet B, Altimir N, Gruenhage L, Ammann C, Cieslik S, Paoletti E, Mikkelsen TN, Ro-Poulsen H, Cellier P, Cape JN, Horváth L, Loreto F, Niinemets Ü, Palmer PI, Rinne J, Misztal P, Nemitz E, Nilsson D, Pryor S, Gallagher MW, Vesala $T$, Skiba U, Brüggemann $N$, Zechmeister-Boltenstern $S$, Williams J, O'Dowd C, Facchini MC, de Leeuw G, Flossman A, Chaumerliac N, Erisman JW (2009) Atmospheric composition change: Ecosystems-atmosphere interactions. Atmos. Environ. 43(33): 5193-5267.

IPCC (2007). Climate Change. The physical science basis. Contribution of working group I to the fourth assessment report of the Intergovernmental Panel on Climate Change. Chapter 1, Historical overview of climate change. Cambridge University Press, Cambridge.

Khonje T (2004). Determination of Carbon monoxide levels in Masauko Chipembere Highway in Blantyre. BSc Thesis, University of Malawi, The Polytechic, Blantyre, Malawi.

Landau S, Everitt BR (2004). A Handbook of Statistical Analyses using SPSS, Chapman \& Hall/CRC Press LLC

Lee SC, Chiu MY, Ho KF, Zou SC, Wang X (2002). Volatile organic compounds (VOCs) in urban atmosphere of Hong Kong. Chemosphere 48: 375-382

Lu W, Wang W, Wang X, Yan S, Lam JC (2004). Potential assessment of a neural network model with PCA/RBF approach for forecasting pollutant trends in Mong Kok urban air, Hong Kong. Environ. Res. 96: 79-87

Makra L, Mayer H, Mika J, Sánta T, Holst J (2010). Variations of traffic related air pollution on different time scales in Szeged, Hungary and Freiburg, Germany. Physics and Chemistry of the Earth, Parts A/B/C 35(1-2): 85-94

Malawi Bureau of Standards (MBS) (2005). Industrial emissions from mobile and stationary Sources- Specification. MS 737:2005. Malawi Standards Board, Blantyre. 
Mendoza A, Gutiérrez AA, Pardo El (2009). Volatile organic compounds in the downtown area of Mexicali, México during the spring of 2005: analysis of ambient data and source-receptor modeling. Atmósfera 22(2): 195-217

Peters A, Liu E, Verrier RL, Schwartz J, Gold DR, Mittleman M, et al. (2000). Air pollution and risk of cardiac arrhythmia. Epidemiology 11:11-7.

Prüss-Üstün A, Corvalán C (2006). Preventing disease through healthy environments. World Health Organization. Geneva (Online) http://www.who.int/quantifying_ehimpacts/publications/en/ accessed $20 / 04 / 2013$

USEPA (2010). "Methane". Methane and Nitrous Oxide Emissions From Natural Sources. [Online] http://www.epa.gov/methane/sources.html (accessed 16th October, 2012).
WHO (2003). Health Aspects of Air Polution with Particulate Matter, Ozone and Nitrogen Dioxide (http://www.euro.who.int/ document/e79097.pdf), pp. 98, EUR/03/5042688, World Health Organisation, Bonn, Germany.

URLhttp://www.draeger.co.uk/sites/en_uk/Pages/Industry/Draeger-Xam-7000.aspx.Accessed18.04.20130penstreetmap. http://www.openstreetmap.org/?box=yes\&bbox=35.02187\%2C$15.80184 \% 2 C 35.03575 \% 2 C-15.80085$. Retrieved on 20-04-2013. 